\title{
Potentials of business model innovation and values-based management approaches in the mining sector
}

\author{
Olaf Drusche, Stefanie Krause \\ Technische Hochschule Georg Agricola, Bochum, Germany
}

\begin{abstract}
Mining is known to cause high ecological and social impacts especially due to its extractive nature on one hand and its resources and reserves mostly being located in developing or emerging economies on the other hand. Thus, it can be considered to have a paramount role in terms of making a significant contribution to sustainable development. Bearing in mind the growing economic output generated by humans and the growing world population, it is no wonder that related human-driven activities have never had such a strong (and at the same time burdening) influence on the biosphere resulting in exceedance of the planetary system boundaries. The critical reflection of the interaction between material cycles and economic growth is essential for reducing environmental burdens resulting from unthinking consumption patterns and production, and initial material extraction. The latest findings in academia confirm this assumption and point out that most practitioners are already aware of the urgent need for a redefinition of the sector's understanding of success, taking into account the needs of both shareholders and stakeholders. Furthermore, the extractive sector has gained an image of being outdated. Agrowing number of decision-makers sees the necessity for a sustainable approach to business models that also embraces digitalization. The purpose of the paper is to analyze the standard business model that still dominates the mining industry, followed by a comparison of recent scientific findings on sustainability-oriented business model innovation and values-based innovation management to derive recommendations for potential sectorspecific business model archetypes that contribute to the urgent redefinition.
\end{abstract}

\section{Introduction}

\subsection{Environmental Motivation}

Mineral raw materials and sustainable development are very closely related since they form the basis of the social development in the current economic system [1]. Driven by scientific and technological advances, the extraction of construction materials has increased 34 -fold, ores and minerals 27-fold, fossil fuels 12-fold, and biomass 3.6-fold [2]. This expansion of consumption causes intense environmental impacts. Due to its current business practices, mining is rightly referred to have a great responsibility in these terms. The same assumption 
applies in terms of social and especially human rights impacts. Meanwhile, societal expectations increase, and people rightly demand that the extractive industry owes to make a greater contribution to sustainable development. Governments are also placing pressure on mining companies [3].

The central questions about whether and under what circumstances, for example, largescale mining projects can contribute to sustainable development remain and if so, to what extent [4]. Over-exploitation, climate change, pollution, health, changes in land use, and loss of biodiversity have become major concerns for the international community. One result is that "sustainable development" is an over-arching global social, environmental, and economic imperative for governments, international organizations, and the private sector [2]. The current economic paradigm has placed enormous pressure on the planet while catering to the needs of only about a quarter of the people on it. It is anticipated, that during the next decade twice that number will become consumers and producers. Traditional approaches to business will collapse, and companies will have to develop innovative solutions [5]. It is no longer enough to preserve life-supporting socio-ecological systems. In this regard, classical management thinking, mainly based on generic strategies, and traditional manufacturing processes will reach their limits pretty soon. In terms of technological aspects, substitution, exploration, modern processing technologies, and product lifecycle thinking, will be major contributors to sustainable products, processes, and service development and at the same time reduce supply risks. The current consumption patterns of (natural) resources will not enable firms to continue their business in the long term - this is proven by the laws of thermodynamics (entropy). For instance, a company in the field of extraction and marketing of critical raw materials will not be able to maintain its position continuously, even if all other factors remain the same in the model. The operating environment changes due to the industrial activities themselves. The mining industry's leaders' awareness seems, at least officially, to be existent. According to the latest KPMG survey, $75 \%$ of its respondents identify the need to better measure and report on success factors beyond financial results, based on the recognition of a wider range of stakeholder perspectives. Furthermore, the survey attests to a notable shift in focus by the industry to a higher regard for holistic measures reflecting ESG-related risks, proved by an increased perception of the relevance of "environmental risks and "tailings management" in particular [6].

\subsection{Social Motivation}

Community relations and obtaining a social license to operate remain one of the top risks for the global mining industry [6]. A social license exists when a mining project is deemed to have broad, ongoing public support for and approval of its activities [7,8], whether or not the law enshrines the initial societal expectations that must be fulfilled to gain that approval and acceptance [9]. But why is that so? Mining stakeholders around the world show a growing awareness for the negative impacts of conventional approaches to mineral development, be it adverse environmental impacts as described before, or particular social and cultural disruption as well as economic instability [8]. It is a proven fact that mining activities mostly take place in emerging or developing countries. Dunbar et al. consider "the myriad of social challenges that now confront the sector" are even more daunting for the future of mining than the technical challenges associated with mineral resource extraction. So to speak, mining is expected to have a more positive influence on the long-term sustainable development of resource-rich communities [3]. The voices of mining-affected communities have gained influence in mineral development decision-making and political processes. Dissatisfaction with the fulfillment of demands of civil society and local communities often results in shutdowns, project slow-downs, protests and blockades, non- 
issuance or retraction of government permits, or media campaigns proving costly for the mining sector, already known as one of the most capital-intensive industries $[3,8,10]$. In mining practice, management's conviction and perception of the relationship between voluntary social or environmental measures and the success of the company, so to speak "mindsets," are important [11]. Managers must rethink their perception of costs that are associated with projects in local communities; for instance, decision-makers must learn that there is real business value in solving societal needs. Otherwise, an immense opportunity will be lost for both mining companies and society [12].

\subsection{Economic Motivation}

The mining and quarrying industry is one of the most capital-intensive industries. According to the latest KPMG survey, access to capital and liquidity remains one of the top 3 risks for running a mining business [6]. The reasons are multifaceted and complicate the long-term planning of (sustainable) mineral production. First, geology defines the occurrence of ore deposits [13]. Prospecting, exploration, and production are dependent on technical conditions and are very capital-intensive. New mining capacities are not built up that quickly. The establishment of a new company for the extraction of mineral raw materials usually takes 5 to 12 years and up to 20 years for large projects. The implementation is carried out in stages, with each stage being based on the results of the previous one. Accordingly, the raw material supply is usually characterized by low flexibility [10]. Most traditional mining regions have already been explored and mined for decades. Thus, the remaining ore bodies are located deeper in the earth's crust, resulting in increasing exploration costs. Alternatively, remote areas with a less developed infrastructure have to be explored. Also, new deposits tend to be of lower grade and the new situation and/or the requirement for optimization presents process engineers with new, costly challenges. Furthermore, exploration investments are never solely dependent on the geological potential but rather also on land access, tourism or recreation purposes, stricter laws and regulations, availability of energy and water, to name just the most prominent risks and restrictions [13]. Despite their potential for economic growth, extraction activities are often linked with missed opportunities for economic development and societal progress. According to McKinsey, almost $80 \%$ of countries whose economies historically have been driven by resources have per capita income levels below the global average. This finding is also depicted in the dreadful ranking of human development indicators in most resourcedriven economies [14]. This lack of societal progress is accompanied by tangible business consequences, e.g. disputes with governments and local communities that result in costly delays and disruptions aside from the bad influence on the company's reputation. According to the International Council on Mining and Metals (ICMM), the number of communicated mining-related community conflicts has increased by more than eight times since $2002[15,16]$.

\section{Values and their implications for the innovation of sustainable business model}

Holistic approaches are increasingly required in the business context and beyond. This also or rather especially applies to the mining sector. Achieving sustainable respectively shared value for all stakeholders, the environment included, is about to become a top priority soon. Managers are discussing what success means to them and their businesses apart from economic measures. The 2020 KPMG Global Mining Survey points out that $75 \%$ of its respondents share the opinion that the mining industry needs to redefine success using a 
more holistic group of measures taking into account the values of all its relevant interest groups including both shareholders and stakeholders. Social values, community stakeholders, health, safety, and long-term development were identified as the key measures in this context [6]. In terms of the mining sector, which is heavily dependent on capital, this demand is currently also driven by economic factors: the trend toward responsible investing is depicted by the environmental, social, and governance (ESG) principles that are considered in the decision-making by both individual investors and institutional asset managers. Factors like climate change, water management, health, and safety, as well as the fair treatment of workers and communities, are being critically reviewed. ESG investing is estimated at more than \$20 trillion in assets under management, and further growth is expected. Mining companies that fail to deliver value beyond compliance have to expect both financial and reputational consequences [17]. Aside from this verification in practical studies, the increasing relevance of multiple values is also depicted in new theoretical interpretations of both strategic and innovation management that imply a new understanding and route of how business shall be done.

Until recently, corporate management was usually based on a unilateral value-oriented approach, also known as "shareholder value management" or "value-based view" that was coined by Rappaport (1986), Stewart (1990) and Copeland et al. (1993) and gained great significance in the past, particularly within the U.S., where the form of the public limited company dominates. According to Breuer and Lüdeke-Freund the "[...] value-based approach prioritizes financial performance goals and measures; benefits such as employment, good treatment of employees, customer satisfaction, and corporate responsibility are more so considered to be positive side-effects. This indicates a subordination of social to financial values" This perspective may be one-to-one translated into pure economic rationality [18].

Contrary to the value-oriented management concept described before, the approach of values-oriented management does not postulate a singular corporate orientation towards quantitative, financial values, but rather towards qualitative values such as moral-cultural, social, or other non-financial values. In this context, values can generally be understood as notions of the desirable, held by individuals or a social group. Firms are required to orient themselves according to the societal set and system of values and to be aware of their role as actors who bear responsibility for society and its development - even beyond the actual business or organizational purpose ("compliance").

According to Breuer and Lüdeke-Freund, values also provide a basis for inspiring, directing, and evaluating innovation. They may serve as a source of innovation as well as viable methods to align personal, organizational, and societal values within and beyond the daily business [18]. The corporate "living" of the associated values-based view translates "those notions of the desirable from the periphery to the heart of corporate value creation and renewal" [18]. But how to operationalize these findings in business practice?

Business models and their innovation are recognized to be an important lever for change and to tackle related sustainability issues identified to be the most pressing [19]. Furthermore, the development of new business models has become a prime technique to achieve unique strategic positions and thus competitive advantages [18]. Chesbrough postulates that "a mediocre technology pursued with a great business model may be more valuable than a great technology exploited via a mediocre business model" [20]. Respondents of the latest KPMG study seem already aware of the potential that lies in business model innovation: according to the survey, 33\% of respondents asserted that today's mining companies need to embrace new business models [6].

In this paper, business models shall be defined as a representation of the organizational value creation, based on a value proposition (the benefit offered to all kinds of stakeholders), value delivery (how those value propositions address and unfold for 
respective interest groups), and value capture (how the focal company obtains net value from its interaction with stakeholders) [18]. Sustainable business models, also known as business models for sustainability, have the potential to become the driver for sustainability-oriented innovation in business. Ideally, this type of business model entails and combines the economic, environmental, and social sustainability perspective on corporate activities and uses a triple-bottom-line approach in measuring performance, considers the needs of all stakeholders rather than prioritizing shareholders' wealth, and considers nature to be one of its stakeholders. It includes both a usual firm-level perspective, but also a systems perspective [21,22] and is therefore suited to meet the aforementioned expectations of mining industries' stakeholders.

Business model innovation is defined as the modification of existing as well as the introduction of new forms of value creation, delivery, and capture, enabling new qualities and/or new configurations of business model components [18]. Sustainable business model innovation outshines incremental product, process, and technological innovations [23] and rather offers an opportunity to integrate sustainability considerations more fully and systematically $[22,24]$ into the mining business.

Bearing in mind the three-dimensional challenges the mining industry (and at the same time planet and humankind) is currently facing, it is more than obvious, that incremental product, process, and technological innovations will not be sufficient. The multitude of demands implies the need for innovative sustainable business models creating multiple values by considering various stakeholders and their value interpretations. The adoption and implementation of innovation offer the extractive sector the opportunity to tackle some of the most pressing identified challenges [25]; not only in terms of sustainability-driven issues but also with regard to the increasing digitalization of corporate activities. Ideally, there will be business model innovation intertwining both corporate levers.

\section{Mining context and the industry's current business model}

\subsection{Mining context and the current business model}

Mining is defined as "the process of extracting metallic, non-metallic mineral or industrial rock deposits from the earth" [26]. In order to properly assess the role of mining, it is important to consider its special position as the first link in a multi-level value chain. The multiplication effect of the extractive industry concerning the production processes of downstream goods and services directly or indirectly dependent on mining is of eminent importance [10]. Minerals are raw materials essential for our society: they are used to build roads and houses, and to produce cars, computers, and household appliances [26, 27]. Thus, the mining and quarrying industry which extracts these minerals is essential to industrial, social, and technological progress and therefore has the chance to take a leadership role in sustainable development. 


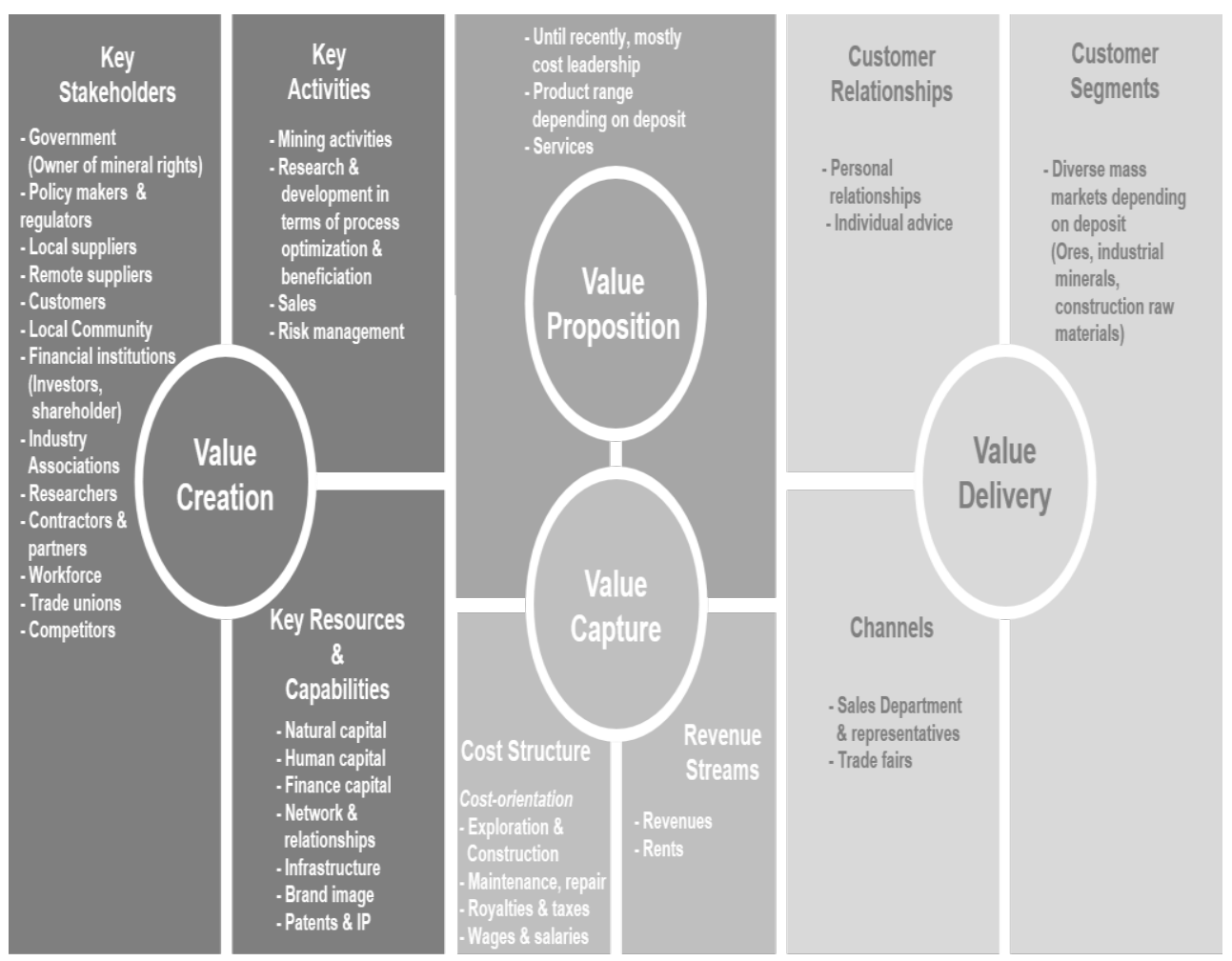

Fig. 1: Current business model in mining (Authors' illustration).

"Mining business as usual"is illustrated in Figure 1 in the form of a visual tool that is widespread both in academia and business practice: the "Business Model Canvas" [28]. The average mining business typically anchored its strategic planning around producing the highest volumes of ore at the lowest possible cost, i.e., cost-oriented cost structure. Its core business activities can be described as selling products from the mine to its customers (revenue streams) and paying royalties and taxes to the government. A network of local and international partners supplies the mine with required equipment and material. If there is engagement between the mine operator, government and the local community, benefits shall arise. It is the local community that determines if the mining project is granted a social license to operate [3]. The current business model is built on a complex network of relationships, characterized by a variety of key stakeholders, a high degree of risk tolerance, in particular that required by investors, and due to its decade-lasting life cycle, an appropriate long-term planning horizon. These business characteristics are accompanied by a rather "thin" value proposition that has to fight eagerness for differentiation and is mostly based on cost leadership. Revenue streams mostly depend on volatile commodity pricing and face high CAPEX and OPEX on the opposite side. The mine has to overcome a long dry spell: once a mining project has proven feasibility which can take several years, the mine manager has to apply to the respective country government for permission to develop and operate the mine, followed by an investment in the construction of the mine [3]. The operation then starts several years after the first prospecting and exploration. One of the difficulties is the "right timing" of the initial investment, capable to turn the cash flow positive within the first years of the mine's lifetime. Only a few companies are willing to invest during a low commodity price cycle which may be hard to predict. The use of many critical minerals, e.g., rare-earth elements, depends on technological development and 
trends [13]. Bearing in mind these assumptions, it is no wonder that the current business model is usually prone to conflicts.

Dunbar points out many possibilities for disruptions in the operation of the described business model that are not induced by technical risks but rather interactions with stakeholders. The main issue "[...] is that benefits accrue disproportionately to shareholders and governments, while impacts are localized to communities" [3]. This permanent risk of losing the social license to operate, on which the mining activities depend upon in practice, cannot be prevented or offset by transactional relationships between the company and the community in the form of philanthropic investment or CSR programs, but rather require a rethinking of value creation [3]. Ideally, mining companies should deliver business, social, and environmental value simultaneously [29, 12]. These findings result in the need for innovation that goes beyond product or process innovation, i.e., a business model innovation, as described before.

Meanwhile, the mining and minerals industry is at a crossroads: it has increasingly gained an image of being outdated and is widely perceived as the opposite of being either sustainable or innovative. Its bad reputation is paid for by a significant loss of attractiveness among the younger generation [13], especially in terms of being an employee or the education of choice. Thus, many universities ended their mining-related curricula in the 1990s, which led to a challenge of rebuilding mining knowledge and competencies [13]. Apart from sustainability-driven issues, the context of mining companies is increasingly determined by the rapid development towards digitalization. Digitalization revolutionizes the way business is conducted within entire industrial value chains by the aid of the use of Internet of Things (IoT) technologies, considerable data exchange, and predictive analytics. Still, the singular application of mere technologies and increasing automation alone is not sufficient [30]. Also, in this case, business model innovation is required.

Nevertheless, it is required not only due to its capital intensity, but also because the industry is prone to lock-in effects and a certain operative and strategic rigidity. According to a PwC study, investors and stakeholders are concerned that the mining industry "is lagging, when it comes to several factors that have not been a traditional focus" [...], e.g., "dealing with emissions, investing in differentiating technology and digitization, engaging more proactively with consumers and building brand" [31]. This perception is also reflected in academia. Research on the diffusion of innovation and technology adoption in the mining sector is a comparatively small, yet growing, research field. The implementation of new technologies will already be characterized by complexity if it entails disruption to existing operational routines $[25,32]$.

\subsection{Sustainability paradigms in mining}

Sustainability and its development are multifaceted and complex subject areas. Numerous definitions and interpretations exist in different disciplines. The Global Mining Initiative (GMI) was launched to define what sustainable development should mean to the industry and how it would contribute. They concluded: "In the context of the minerals sector, the goal should be to maximize the contribution to the well-being of the current generation in a way that ensures an equitable distribution of its costs and benefits, without reducing the potential for future generations to meet their own needs. The approach taken to achieve this has to be both comprehensive, including the whole minerals chain, and forward-looking, setting out long-term as well as short-term objectives.” [33].

Hilson and Murck developed sustainability guidelines for mining companies that translate "sustainability in mining" into six practical recommendations: (1) improved planning; (2) improved environmental management; (3) cleaner technology 
implementation; (4) increased stakeholder involvement; (5) formation of partnerships, and (6) improved training [34].

The question remains, if this definition on the one hand, and those exemplary sustainability guidelines on the other hand, also represent the stakeholders' demands. Furthermore, do these assumptions already mark the end of the line with regard to the industry's maximum possible contribution to sustainable development?

Two main economic paradigms of sustainable development dominate in theoretical research: the weak sustainability (or substitutability) paradigm [35] which may be interpreted as an extension to neoclassical welfare economics [36-38]. Its proponents regard natural capital to be essentially substitutable in the production of consumption goods and as a direct provider of utility. According to this paradigm, it is only the total aggregate stock of manmade, human, and natural capital, but not natural capital as such, that counts for future generations [35]. Within the scope of the weak sustainability paradigm, technical progress gains a paramount role and is seen as the enabler that relativizes the finite nature of natural resources and the resulting limitation of economic growth [36]. To put it in other words, it is technical progress that enables the substitution of natural resources (technology optimism). Such a position leads to maximizing monetary compensations for environmental degradation. The question "if it pays off" dominates (exploration of new deposits and recycling become economical with increasing prices, thus leading to better supply and, consequently, decreasing prices, and eased economic scarcity).

Humanity can only use certain raw materials economically because of their physical concentration in individual deposits. Mining activities cause a continuous change in the composition of deposits. The concentration of elements steadily decreases and, at the same time, their distribution increases (second law of thermodynamics). The result: our world is changing irreversibly. It is in the inner essence of time that causes the entropy to increase irreversibly; only the rate of entropy increase can be influenced. The more effectively mineral resources are utilized, the faster entropy increases, reflecting the larger and more likely distribution of materials. However, the growing distribution of raw materials results in an increasing degree of difficulty, if not even to impossibility, to reuse them. From a certain distribution, the elements are lost and thus withdrawn from the technical and economic access. The increase in entropy can only be counteracted [40].

In opposition to the weak sustainability paradigm [35], the strong sustainability (or nonsubstitutability) paradigm regards natural capital as non-substitutable, in the production of consumptions goods (source), in its capacity to absorb pollution (sink) and as a direct provider of utility in the form of environmental amenities. As regards the latter, two differing interpretations exist: one demands to preserve natural capital in value terms, the other one demands to preserve the physical stocks of certain forms of defined critical natural capital [35]. Since manufactured capital requires natural capital for its production, it can never be a full substitute for the biophysical structures of natural capital. Certain elements of natural capital are "critical" due to their unique contribution to human wellbeing [41]. The term "critical" is generally applied to elements of nature that are both irreplaceable or irreparable and currently scarce. Some elements, for instance, rare-earth elements that are increasingly required in applications for future green technology (e.g., emobility and wind power), cannot be easily substituted due to their characteristics and, at the same time, an exceptionally low recycling rate, are therefore considered as critical and irreplaceable. This example shows a contradiction: any use of non-renewable resource can be classified as unsustainable unless one of the following conditions is met:

- The resource is so abundant, as is present in forms that can be accessed for low energy and resource costs, that there is no possibility of ever experiencing any scarcity within any meaningful timeframe. 
- There are mechanisms to recover and recycle the resource within the economy with a high degree of efficiency [42]

There is an ongoing debate about whether the mining sector is or could be sustainable, and if so, to what extent. Tost et al. (2018) conducted research in which they found that concepts supporting "strong sustainability" in general dominate in academia but have not yet become mainstream [1]. Mining is no exception in this context. Like in many other branches, the neoclassical influence is still clearly noticeable. How ores and minerals should be extracted, processed, used, and recycled in the context of sustainable development is less than obvious and often bitterly controversial. Even though Environmental Economics and its strong sustainability concept both provide managers with a more realistic perspective of their corporate context and their stakeholders' demands, and would also implement a much greater contribution to sustainable development, it has to be pointed out that achieving the desired "strong sustainability" is so far not feasible in some branches. According to the findings of Allan, obviously referring to Daly's management rules for contributing to sustainable development, sustainable mining could exist if the rate of use of minerals did not exceed the capacity to find new sources, acceptable substitutes or recycle. Furthermore, sustainable mining also includes an environmental component, and miners should use the land with care $[43,44]$

The guiding principle of sustainable development has a normative character: it is oriented towards the realization of human needs and requires that current developments be assessed for sustainability and future developments. Based on the aforementioned considerations, the path towards an environmental economy is inevitable. Responsibility for the future requires resources to be passed on to future generations as undiminished or even expanded as possible [45]. Still, the practical implementation of the extreme position of the strong sustainability paradigm, requiring the complete renunciation of the use of nonrenewable natural resources (living only according to the interest of natural capital), leads to the paradox that the existing potential of non-renewable resources (such as rare- earth elements) should not be used at all. Thus, the elements would be irretrievably lost after use and would not be available to present or future generations [46]. How do these assumptions apply to the mining sector? Like in many other cases, the world is not only black or white. Still, it is important to strive for a central position between the two extremes that supports sustainable development beyond mere technological progress in products or processes. Innovations, in particular business model innovations, interpreted holistically and considering all kinds of stakeholders and their individual values, may provide the required new solutions in mining.

\section{Sustainable business model: archetypes in mining}

Because of extracting and processing mineral resources, the mining industry is widely regarded as one of the most environmentally and socially disruptive business activities in the world [47]. Indeed, many of the major environmental disasters and human rights incidents that have led to growing public concern of the stakeholders about sustainable development have taken place in the mining industry. Aspects of maintaining a social license to operate play an increasingrole in this discussion. Whereby the social license to operate reflects an informal social contract that aims to bridge the gap among the views of the most important stakeholders involved in mining activities [48]. In doing so, the central challenge is to produce raw materials economically and with a reduction in environmental effects and social impacts like failures of the tailings dams. Water conservation and the cost of tailings and reclamation are also becoming increasingly significant factors for sustainable and economically viable mining and long-term survival [49]. In a more global 
context, in the evolvement of the risks landscape, a significant shift from economic to environmental risks is visible over the last decades. Environmental risks continue to dominate the results of the annual Global Risks Perception Survey (GRPS). In 2019, they accounted for three of the top five risks by likelihood and four by the impact. The results of climate inaction are becoming increasingly clear. The accelerating pace of biodiversity loss is a particular concern. Man-made environmental damage and natural disasters result in environmental degradation, reduced quality of the air, soil, and water due to ambient concentrations of pollutants in the environment and other activities and processes (World Economic Forum, 2019). For a deeper appreciation of the extent of risks, the example of the rare-earth elements (REEs), such as Nd and Dy, and their supply chain, which has been linear so far, illustrates how disruption may play out. The current circular use of critical raw materials, to be specific, the End-Of-Life Recycling Input Rate (EOL-RIR) of REEs is currently between 6 and 7\% [50]. These elements create critical inputs for advanced industries. Rare-earths are critical in aerospace and defense, electric vehicles, wind turbines, drones, medical appliances, and other electronics. The supply chain is currentlygeographically highly concentrated in regions with an increasing probability of relevant climate hazards which might lead to landslides or dam failures. However, this is only one example illustrating the much broader picture of risks in the broader sense and the consequent relevance of adequate risk management.

Business models for sustainability are seen as both the powerful lever for the operationalization of the sustainability strategies and the alignment of their respective criteria, like eco-efficiency, eco-effectiveness, sufficiency, ecological equity, socioefficiency, and socio-effectiveness [51]. Within the raw materials sector, they can reduce hazards and vulnerability, through the frequency of events and the number of damages. In the nexus of this article, the generally sustainable business model archetypes identified by [52] were selected as a starting point for a comprehensive framework, bringing together innovations from research and practice. These include nine sustainable business archetypes (Table 1), categorized according to generic classification, namely technological, social, and organizational innovation, based on the major innovation types identified by [53]. The business models of firms in the raw materials sector need to be changed towards a direction of Product/Service-Systems (PSSs), and/or, even better, to emerging concepts of Material/Service-Systems (MSS), which offer the opportunities for value creation and capture through the application of circular strategies to reach the desired corporate longevity [54,55]. Considering the paradigm of strong sustainability requires a transdisciplinary approach for identifying and conserving critical natural capital. The knowledge provided by natural science constitutes crucial contributions for identifying ecological thresholds and planetary boundaries, but they are not solely sufficient. Natural science research needs to be combined with social and economic sciences and their interactions need to be embedded in a broad societal debate about (i) levels of risk acceptable to all populations (especially the most vulnerable populations) and (ii) values that underlie human development [56].

Table 1: List of sustainable business model archetypes referring to [52] analyzed concerning usability in the mining context (Authors' illustration)

\begin{tabular}{|c|c|c|c|c|}
\hline Pattern & $\begin{array}{c}\text { Value } \\
\text { proposition }\end{array}$ & $\begin{array}{c}\text { Value creation \& } \\
\text { delivery }\end{array}$ & Value capture & $\begin{array}{c}\text { The difference } \\
\text { from mainstream } \\
\text { raw materials } \\
\text { sector business } \\
\text { model }\end{array}$ \\
\hline $\begin{array}{c}\text { Maximize material } \\
\text { and }\end{array}$ & $\begin{array}{c}\text { Processes that } \\
\text { use fewer }\end{array}$ & $\begin{array}{c}\text { The focus is on } \\
\text { the internal }\end{array}$ & $\begin{array}{c}\text { Costs are } \\
\text { reduced through }\end{array}$ & $\begin{array}{c}\text { Mining companies } \\
\text { intend to }\end{array}$ \\
\hline
\end{tabular}




\begin{tabular}{|c|c|c|c|c|}
\hline $\begin{array}{c}\text { energy } \\
\text { efficiency }\end{array}$ & $\begin{array}{l}\text { resources, } \\
\text { generating less } \\
\text { waste and } \\
\text { emissions than } \\
\text { the processes } \\
\text { that deliver } \\
\text { similar } \\
\text { functionality. }\end{array}$ & $\begin{array}{l}\text { operational } \\
\text { process } \\
\text { innovation. }\end{array}$ & $\begin{array}{l}\text { increased } \\
\text { operational } \\
\text { efficiency } \\
\text { leading to } \\
\text { increased } \\
\text { profits. }\end{array}$ & $\begin{array}{c}\text { implement a } \\
\text { broader strategy to } \\
\text { maximize material } \\
\text { and energy } \\
\text { efficiency instead } \\
\text { of a piecemeal } \\
\text { approach. }\end{array}$ \\
\hline $\begin{array}{l}\text { Closing resource } \\
\text { loops }\end{array}$ & $\begin{array}{l}\text { Reduction of } \\
\text { waste. } \\
\text { Controlling } \\
\text { flows of material } \\
\text { resources and } \\
\text { take control over } \\
\text { materials flows. }\end{array}$ & $\begin{array}{l}\text { Turns waste into } \\
\text { value. (Industrial } \\
\text { symbiosis) }\end{array}$ & $\begin{array}{l}\text { Generation of } \\
\text { new revenue } \\
\text { streams. } \\
\text { Building } \\
\text { business thatis } \\
\text { based on } \\
\text { services and } \\
\text { partnerships } \\
\text { rather than } \\
\text { single } \\
\text { transactions of } \\
\text { finite resources. }\end{array}$ & $\begin{array}{l}\text { Motivation and } \\
\text { encouragement to } \\
\text { exert control on } \\
\text { systems across the } \\
\text { resource lifecycle, } \\
\text { as returning } \\
\text { resource flows are } \\
\text { seen as creating } \\
\text { value and } \\
\text { suppliers have a } \\
\text { demand for their } \\
\text { used product. } \\
\text { Open to digital } \\
\text { innovations. }\end{array}$ \\
\hline $\begin{array}{l}\text { Substitute/Use of } \\
\text { renewable and } \\
\text { digital processes }\end{array}$ & $\begin{array}{c}\text { Reduce } \\
\text { environmental } \\
\text { impacts and } \\
\text { increase } \\
\text { business } \\
\text { resilience in } \\
\text { terms of power } \\
\text { supply by using } \\
\text { renewable power } \\
\text { sources and } \\
\text { electronic means } \\
\text { in the service } \\
\text { delivery process }\end{array}$ & $\begin{array}{l}\text { Innovation in } \\
\text { service delivery } \\
\text { design (e.g. } \\
\text { delivery } \\
\text { channels) } \\
\text { enhances the } \\
\text { cost and } \\
\text { accuracy of } \\
\text { service delivery } \\
\text { to customers. }\end{array}$ & $\begin{array}{l}\text { Revenue is } \\
\text { enhanced by } \\
\text { providing } \\
\text { customers more } \\
\text { convenience, } \\
\text { which may } \\
\text { result in more } \\
\text { frequent } \\
\text { transactions. } \\
\text { Cost-saving is } \\
\text { achieved by } \\
\text { reducing } \\
\text { manpower and } \\
\text { related } \\
\text { expenses. }\end{array}$ & $\begin{array}{l}\text { Firms in the raw } \\
\text { materials sector } \\
\text { keep innovating } \\
\text { with digital } \\
\text { processes for } \\
\text { customer contact } \\
\text { with a target to } \\
\text { minimize or } \\
\text { eliminate } \\
\text { traditional branch } \\
\text { networks. } \\
\text { Accelerated by } \\
\text { COVID -19 } \\
\text { pandemic. }\end{array}$ \\
\hline $\begin{array}{c}\text { Deliver } \\
\text { functionality, not } \\
\text { ownership (MSS) }\end{array}$ & $\begin{array}{l}\text { Can encourage } \\
\text { the right } \\
\text { behaviors with } \\
\text { manufacturer s } \\
\text { and users. }\end{array}$ & $\begin{array}{l}\text { Can reduce the } \\
\text { need for physical } \\
\text { goods. }\end{array}$ & $\begin{array}{l}\text { Ability to react } \\
\text { to volatile raw } \\
\text { material prices. }\end{array}$ & $\begin{array}{l}\text { Ability to exert } \\
\text { control on } \\
\text { material resources } \\
\text { prior to and after } \\
\text { use. }\end{array}$ \\
\hline $\begin{array}{c}\text { Adopt a } \\
\text { stewardship role }\end{array}$ & $\begin{array}{l}\text { Provision of } \\
\text { products } \\
\text { intended to } \\
\text { genuinely and } \\
\text { proactively } \\
\text { engage with } \\
\text { stakeholders to }\end{array}$ & $\begin{array}{c}\text { Ensuring } \\
\text { activities and } \\
\text { partners are } \\
\text { focused on } \\
\text { delivering } \\
\text { stakeholders' } \\
\text { well-being. The }\end{array}$ & $\begin{array}{l}\text { Generation of } \\
\text { brand value, } \\
\text { potential cost } \\
\text { savings, and } \\
\text { secure future } \\
\text { business. } \\
\text { Stakeholders' }\end{array}$ & $\begin{array}{l}\text { In addition to the } \\
\text { traditional CSR } \\
\text { activities, firms in } \\
\text { the raw materials } \\
\text { sector tend to } \\
\text { adopt a shared } \\
\text { value approach to }\end{array}$ \\
\hline
\end{tabular}




\begin{tabular}{|c|c|c|c|c|}
\hline & $\begin{array}{l}\text { ensure their } \\
\text { long-term well- } \\
\text { being. Broader } \\
\text { benefits to } \\
\text { stakeholders } \\
\text { often become an } \\
\text { important aspect } \\
\text { of the value } \\
\text { proposition by } \\
\text { engaging } \\
\text { customers better. }\end{array}$ & $\begin{array}{l}\text { value chain is } \\
\text { ensured to } \\
\text { deliver } \\
\text { environmental or } \\
\text { social benefits. }\end{array}$ & $\begin{array}{c}\text { wellbeing } \\
\text { generates long- } \\
\text { term business } \\
\text { benefits. For } \\
\text { example, } \\
\text { healthy and } \\
\text { happy staff may } \\
\text { claim fewersick } \\
\text { days and be } \\
\text { more } \\
\text { productive. }\end{array}$ & $\begin{array}{c}\text { leverage and } \\
\text { benefit their core } \\
\text { business, } \\
\text { especially in terms } \\
\text { of local } \\
\text { communities } \\
\text { and/or health and } \\
\text { safety. }\end{array}$ \\
\hline $\begin{array}{l}\text { Encourage } \\
\text { sufficiency }\end{array}$ & $\begin{array}{l}\text { Solutions that } \\
\text { seek to reduce } \\
\text { demand (which } \\
\text { was generally } \\
\text { inflated before) } \\
\text { by correct } \\
\text { assessment of } \\
\text { customer needs } \\
\text { and reducing } \\
\text { misselling of } \\
\text { products and } \\
\text { moral hazard. } \\
\text { The focus is on } \\
\text { the customer } \\
\text { relationship and } \\
\text { reward system. }\end{array}$ & $\begin{array}{l}\text { This may } \\
\text { involve } \\
\text { changing the } \\
\text { frontline sales } \\
\text { staff's } \\
\text { remuneration to } \\
\text { a higher portion } \\
\text { of fixed salary, } \\
\text { promoting need- } \\
\text { based selling by } \\
\text { correct matching } \\
\text { of products, and } \\
\text { advocating } \\
\text { sensible } \\
\text { borrowing. }\end{array}$ & $\begin{array}{c}\text { Customer } \\
\text { satisfaction and } \\
\text { loyalty may } \\
\text { increase } \\
\text { whichmay lead } \\
\text { to more } \\
\text { business. } \\
\text { Compliance risk } \\
\text { is lowered and } \\
\text { reduces the } \\
\text { chance of } \\
\text { penalties by } \\
\text { regulators. } \\
\text { Societal benefit } \\
\text { is captured: } \\
\text { customers get } \\
\text { what they need } \\
\text { in the right } \\
\text { quantity and } \\
\text { quality. }\end{array}$ & $\begin{array}{l}\text { Firms in the raw } \\
\text { materials sector } \\
\text { give up the } \\
\text { approach of } \\
\text { "selling more" by } \\
\text { replacing it with } \\
\text { premier materials } \\
\text { thatmatch the } \\
\text { exact needs of } \\
\text { customers. } \\
\text { Creating new B2B } \\
\text { target groups by } \\
\text { fostering } \\
\text { sufficient behavior } \\
\text { from the end of } \\
\text { the valuechain to } \\
\text { its beginning. }\end{array}$ \\
\hline $\begin{array}{c}\text { Repurpose for } \\
\text { society/environment }\end{array}$ & $\begin{array}{l}\text { Creating societal } \\
\text { benefits and } \\
\text { environmental } \\
\text { benefits through } \\
\text { specializing in } \\
\text { providing } \\
\text { materials that } \\
\text { match the needs } \\
\text { of the customers. }\end{array}$ & $\begin{array}{c}\text { Mining } \\
\text { companies are } \\
\text { using } \\
\text { sustainability as } \\
\text { a criterion for } \\
\text { selecting } \\
\text { customers and } \\
\text { suppliers. }\end{array}$ & $\begin{array}{l}\text { Only provide } \\
\text { materials and } \\
\text { services to } \\
\text { sustainable } \\
\text { companies and } \\
\text { the } \\
\text { disadvantaged, } \\
\text { including } \\
\text { "positive } \\
\text { screening" } \\
\text { against social } \\
\text { and } \\
\text { environmental } \\
\text { benchmarks. }\end{array}$ & $\begin{array}{c}\text { Mining } \\
\text { shouldselect its } \\
\text { partners more } \\
\text { accurately } \\
\text { according to } \\
\text { adherence to } \\
\text { sustainability } \\
\text { standards, not just } \\
\text { using the current } \\
\text { negative screening } \\
\text { approach. }\end{array}$ \\
\hline $\begin{array}{l}\text { Inclusive value } \\
\text { creation }\end{array}$ & $\begin{array}{c}\text { Sharing } \\
\text { resources, skills, }\end{array}$ & $\begin{array}{c}\text { Create new } \\
\text { business }\end{array}$ & $\begin{array}{l}\text { Generation of } \\
\text { new revenue }\end{array}$ & $\begin{array}{c}\text { Collaborative } \\
\text { platforms. }\end{array}$ \\
\hline
\end{tabular}




\begin{tabular}{|c|c|c|c|c|}
\hline & $\begin{array}{c}\text { and knowledge } \\
\text { and distribute } \\
\text { wealth Leverage } \\
\text { resources and } \\
\text { talents. }\end{array}$ & opportunities. & $\begin{array}{c}\text { streams. } \\
\text { Building } \\
\text { business thatis } \\
\text { based on } \\
\text { services and } \\
\text { partnerships. }\end{array}$ & $\begin{array}{c}\text { Collaborative } \\
\text { consumption. }\end{array}$ \\
\hline $\begin{array}{c}\text { Develop scale-up } \\
\text { solutions }\end{array}$ & $\begin{array}{c}\text { Achieve scale }- \\
\text { from the small } \\
\text { entrepreneur or } \\
\text { start-up to } \\
\text { business. }\end{array}$ & $\begin{array}{c}\text { Create new } \\
\text { business } \\
\text { opportunities. }\end{array}$ & $\begin{array}{c}\text { Create } \\
\text { breakthrough } \\
\text { innovation. }\end{array}$ & $\begin{array}{c}\text { Creation of } \\
\text { industry-wide } \\
\text { change or rather a } \\
\text { transition. }\end{array}$ \\
\hline
\end{tabular}

\section{Conclusion}

Sustainability-oriented business models in this specific context shall be considered both as an enabler and as a lever for the alignment of the sustainability management to lead effectively to overall sustainable development and transition to a system change [57]. Common to all models is the key role of innovations, which relates to different areas of the sustainability dimensions.

While resource efficiency makes sense at the firm-level and offers room for improvement, the industry-wide impact is not there yet. Historically, efficiency improvements have generally not proven successful in reducing the overall consumption of human energy resources [58]. Nevertheless, the authors see energetic advantages in the simultaneous use of primary and secondary raw materials. The improvement in profitability, in particular through higher resource productivity, that is, the pursuit and establishment of the efficiency strategy [59]. However, the limitation in the use of secondary raw materials is their availability, which is controlled by the lifespan of the products and the efficiency of collection and recycling. Assuming that only about $70 \%$ of the current human-made flows of solid materials cannot be technically circulated at all, because the majority of them never enter the production cycle, system innovations are necessary for decoupling [60].

Mining should adopt and fully embrace the principle of the circular economy, considering that the extraction of primary resources will retain a key role in the future due to rising demand. Still, mining companies will experience considerable pressure while the recycling rates will rise. Although several critical raw materials have a high recycling potential, especially in terms of reuse and remanufacturing, and despite the encouragement from governments to move towards a circular economy, the end-of-life recycling input rate of critical raw materials like rare-earth elements is currently low. This can be explained by several factors: for many elements, sorting and recycling technologies are not available yet at competitive costs. Furthermore, it is impossible to recover materials that are in the process of dispersed use; the supply of many critical raw materials is currently locked up in long-life assets, hence implying delays between manufacturing and scrapping and therefore directly influencing the recycling input rate [61]. This idea is in line with UNEP's International Resource Panel (IRP) concept of "decoupling" which means using fewer resources per unit of economic output and reducing the environmental impact of any resources that are used or economic activities that are undertaken. Beneath changes in government policies, the key to decoupling in practice will be innovations that enable increasing resource efficiency, thereby reducing metabolic rates. Increasing resource efficiency may also justify increasing resource prices, benefitting resource producers (often in developing countries). Innovation with regard to resource efficiency, thus, may remain 
the core challenge for sustainable resource management for the coming decades. Beneath the classic approaches of exploration of new deposits and the increase of resource efficiency, the enlargement of current linear business models to closed-loop ("circular") business models, contains the potential of desired corporate longevity [62].

The concept of strong sustainability requires that each form of capital be kept constant. Business models for sustainability, inspired by strong sustainability, point out whether companies create values while ensuring that environmental and social impact is in total constant. Therefore, it considers both, corporate eco- and social efficiency, and (natural) resource consumption -environmental and social effectiveness. Augmenting end-to-end performance of a value chain that considers mine-to-market business models shall be a key source of future value creation. Mining companies must consider the big picture of the socioeconomic system and future valuable resources. Currently, predominantly disjointed responsibilities restrict their opportunities.

Olaf Drusche and Stefanie Krause gratefully acknowledge financial support from the German Federal Ministry of Education and Research (BMBF) in the framework of the REGINA - Rare Earth Global Industry and New Applications - project (funding number 033R185B), promoted within the Framework Program FONA - Forschung für nachhaltige Entwicklung, under the funding priority CLIENT II - International Partnerships for Sustainable Innovation.

\section{References}

1. M. Tost, M. Hitch, V. Chandurkar, P. Moser, S. Feiel, The state of environmental sustainability considerations in mining, Journal of Cleaner Production, 7, 969 (2018).

2. UNEP. Decoupling natural resource use and environmental impacts from economic growth. A Report of the Working Group on Decoupling to the International Resource. (Nairobi, Paris: United Nations Environment Programme 2011).

3. W. S. Dunbar, J. Fraser, A. Reynolds, N. C. Kunz, Mining needs new business models, The Extractive Industries and Society, 7, 263 (2020).

4. L. Zarsky, L. Stanley, Can Extractive Industries Promote Sustainable Development? A Net Benefits Framework and a Case Study of the Marlin Mine in Guatemala, The Journal of Environment \& Development, 22(2), 131 (2013).

5. R. Nidumolu, C. Prahalad, M. Rangaswami, Why Sustainability is now the Key Driver of Innovation, Harvard Business Review, 87(9), 56 (2009).

6. KPMG, I. C., Risks and opportunities for mining. Global Outlook. Australia: KPMG. Retrieved August 03, 2020, from https://assets.kpmg/content/dam/kpmg/xx/pdf/2020/02/risks-and-opportunities-formining.pdf (2020)

7. S. Joyce, I. Thomson, Earning a social license to operate: social accetability and resource development in Latin America, Canadian Mining and Metallurgical Bulletin, 93, 49 (2000).

8. J. Prno, D. S. Slocombe, Exploring the origins of 'social license to operate' in the mining sector: Perspective from governance and sustainability theories, Resources Policy, 37, 346 (2012).

9. N. Gunningham, N. Kagan, D. Thornton, Social licence and environmental protection: why businesses go beyond compliance, Law \& Social Inquiry, 29, 307 (2004).

10. G. Tiess, Rohstoffpolitik in Europa. Bedarf, Ziele, Ansätze (Wien, New York: Springer Verlag 2009). 
11. S. Schaltegger, Wie man mit Nachhaltigkeit langfristig im Wettbewerb gewinnt, Lohnt sich Nachhaltigkeitsmanagement? Mindsets, "Business Cases" und Strategie. In T. Wunder, CSR und Strategisches Management. 81 (2017).

12. C. Hidalgo, K. Peterson, D. Smith, H. Foley, Extracting with Purpose. Creating Shared Value in the Oil and Gas and Mining Sectors' Companies and Communities. Shared Value Initiative (FSG 2014).

13. P. A. Nurmi, Green Mining - A Holistic Concept for Sustainable and Acceptable Mineral Production, Annals of Geophysics, 7, 1 (2017).

14. M. G. McKinsey, Reverse the Curse: Maximizing the Potential of Resource-driven Economies. Industry Report, (London, UK: McKinsey Global Institute 2013).

15. ICMM I. C., Analytical Framework. The Challenge of Mineral Wealth: Using Resource Endowments to Foster Sustainable Development, (London, UK: ICMM 2006).

16. R. Hodge, , Mining company performance and community conflict: moving beyond a seeming paradox. Journal of Cleaner Production, 84(1): 27-33, (2014)

17. D. T. Deloitte, Deloitte Insights - Tracking the trends. Leading from the front, (UK: Deloitte 2020).

18. H. Breuer, F. Lüdeke-Freund, Values-Based Innovation Management. Innovating by What We Care About, (Houndmills: Palgrave Macmillan 2017).

19. N. M. Bocken, S. W. Short, Environmental Innovation and Societal Transitions, Towards a sufficiency-driven business model: Experiences and opportunities, 41 (2016).

20. H. Chesbrough, Business Model Innovation: Opportunities and Barriers. Long Range Planning, 43, 354 (2010).

21. N. Bocken, Business models for sustainability. In W. L. Filho, A. M. Azul, L. Brandli, P. G. Özuyar, \& T. Wall, Decent Work and Economic Growth. Encyclopedia of the UN Sustainable Development Goals. (Cham, CH: Springer Nature Switzerland AG 2019).

22. W.Stubbs, C. Cocklin, Conceptualizing a "Sustainability Business Model", Organization \& Environment, 21, 103 (2008).

23. N. Bocken, S. W. Short, P. Rana, S. Evans, A literature and practice review to develop sustainable business model archetypes, Journal of Cleaner Production, 65, 42 (2014)

24. E. Guldmann, N. M. Bocken, H. Brezet, A Design Thinking Framework for Circular Business Model Innovation, Journal of Business Models, 7, 39 (2019).

25. J. H. Gruenhagen, R. Parker, Factors driving or impeding the diffusion and adoption of innovation in mining: A systematic review of the literature, Resources Policy, 65, 1 (2020).

26. European Commission INSPIRE Registry. Retrieved August 19, 2020, from INSPIRE

Feature Concept Dictionary 'Mining Activity':
https://inspire.ec.europa.eu/featureconcept/MiningActivity (2020)

27. F. P. Carvalho, Mining industry and sustainable development: time for change, Food and Energy Security, 6, 61 (2017).

28. A. Osterwalder, Y. Pigneur, Business Model Generation, (Hoboken, New Jersey: John Wiley \& Sons, Inc 2010).

29. M. E. Porter, M. R. Kramer, Creating Shared Value. How to reinvent capitalism - and unleash a wave of innovation and growth, Harvard Business Review, 62 (2011). 
30. V. Parida, D. Sjödin, W. Reim, Reviewing Literature on Digitalization, Business Model Innovation, and Sustainable Industry: Past Achievements and Future Promises. Sustainability, 11, 391 (2019).

31. PwC. Mine. Resourcing the future, (Australia: PwC 2019).

32. C. Nuur, L. Gustavsson, S. Capability creation in the natural resource-based sector: experiences from Swedish mining, Laestadius, innovation and Development, 8,103 (2018).

33. Mining, Minerals and Sustainable Development Project (MMSD), Breaking New Ground: Mining, Minerals and Sustainable Development, (London : International Institute of Environment and Development (IIED) 2002).

34. G. Hilson, B. Murck, Sustainable development in the mining industry: clarifying the corporate perspective, Resources Policy, 26, 227 (2000).

35. E. Neumayer, Weak versus Strong Sustainability. Exploring the Limits of Two Opposing Paradigms (4th Edition ed.), (Cheltenham (UK): Edward Elgar Publishing Ltd 2013).

36. R. M Solow, Intergenerational Equity and Exhaustible Resources, Review of Economic Studies, 29 (1974).

37. R. M Solow, The Economics of Resources or the Resources of Economics, American Economic Review, 2, 1 (1974).

38. R. M Solow, Sustainability: An Economist's Perspective. In R. Dorfman, \& $N$. Dorfman, Selected Readings in Environmental Economics, (New York: Norton 1993).

39. J. Stiglitz, Growth with Exhaustible Natural Resources: Efficient and Optimal Growth Paths, The Review of Economic Studies, 41, 123 (1974).

40. W. Vieweg, Nachhaltige Marktwirtschaft. Eine Erweiterung der Sozialen Marktwirtschaft (Wiesbaden: Springer Fachmedien Wiesbaden GmbH 2019).

41. P. Ekins, S. Simon, L. Deutsch, C. Folke, R. De Groot, A Framework for the practical application of the concepts of critical natural capital and strong sustainability (2003).

42. A. M. Clayton, N. J. Radcliffe, Sustainability. A Systems Approach. (London: Earthscan Publications Ltd 1996).

43. R. Allan, Sustainable mining in the future, Journal of Geochemical Exploration, 52, 1 (1995).

44. H. E. Daly, J. Farley, Ecological economics: Principles and applications, (Washington, D.C.: Island Press 2011).

45. World Commission on Environment and Development, (Brundtland) Report of the World Commission on Environment and Development. Our Common Future. United Nations. (1987).

46. A. Grunwald, J. Kopfmüller, Nachhaltigkeit, (Frankfurt am Main: Campus 2012).

47. P. Peck, K. Sinding, Business Strategy and the Environment, Environmental and Social Disclosure and Data-Richness in the Mining Industry, 131 (2003).

48. K. Komnitsas, Social License to Operate in Mining: Present Views and Future Trends, Resources, 1 (2020).

49. N. Hälleval, Metso Mining. Retrieved from Towards safer, more sustainable handling of mine tailings: https://www.metso.com/blog/mining/sustainable-handling-of-minetailings/ (2020)

50. European Commission - Internal Market, Industry, Entrepreneurship and SMEs. Retrieved August 19, 2020, from Minerals and non-energy extractive industries: https://ec.europa.eu/growth/sectors/raw-materials/industries/minerals_en EC, E. C. (2020). 
51. T. Dyllick, K. Hockerts, Beyond the Business Case for Corporate Sustainability, Business Strategy and the Environment, 11, 130 (2002).

52. N. Bocken, F. Boons, C. Baldassarre, Sustainable business model experimentation by understanding ecologies of business models, Journal of Cleaner Production, 1498 (2019).

53. F. Boons, F. Lüdeke-Freund, Business Models for Sustainable Innovation: State of the Art and Steps Towards a Research Agenda, Journal of Cleaner Production, 9 (2013).

54. F. Blomsma, M. Tennant, G. Brennan, Beyond Product/Service Systems and towards configurations of circular strategies, business models and actors. (Hamburg, London, Dublin, Deutschland/UK/Ireland, 2020).

55. T. Rau, S. Oberhuber, Material Matters, (Berlin: Ullstein, 2018).

56. J. Pelenc, J. Ballet, T. Dedeurwaerdere, Weak Sustainability versus Strong Sustainability. Brüssel/Bordeaux/Louvain, Belgien/Frankreich (2015).

57. T. Wunder, Rethinking Strategic Management. (Cham, Switzerland: Springer Nature 2019).

58. J. B. Dahmus, Can Efficiency Improvements Reduce Resource Consumption? Journal of Industrial Ecology, 883 (2014).

59. F.-W. Wellmer, C. Hagelüken, The Feedback Control Cycle of Mineral Supply, Increase of Raw Material Efficiency, and Sustainable Development, Minerals, 815 (2015)

60. N. Paech, K. Dutz, M. Nagel, Obsoleszenz, Kreislaufwirtschaft in der EU, Nutzungsdauerverlängerung und neue Bildungskonzepte. In S. Eisenriegler, Wiesbaden: Springer Fachmedien. 159 (2020).

61. European Commission. Report on Critical Raw Materials and the Circular Economy. Luxembourg: European Union. (2018).

62. C. Deckert, uwf Umwelt Ecological sustainability of material resources - Why material efficiency just isn't enough, Wirtschafts Forum, 325 (2016). 